
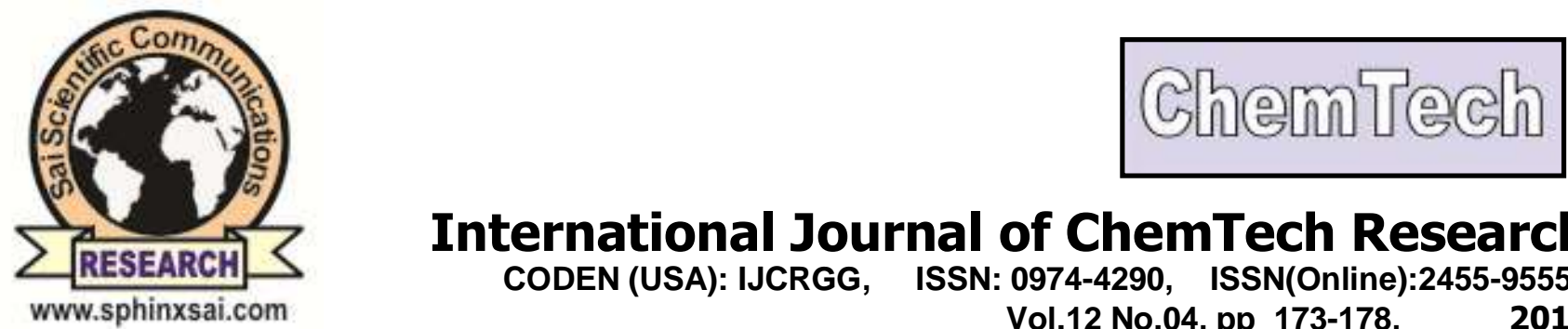

International Journal of ChemTech Research CODEN (USA): IJCRGG, ISSN: 0974-4290, ISSN(Online):2455-9555

Vol.12 No.04, pp 173-178,

2019

\title{
Studies on Water Quality Index of Ground Water in Budigumma Village, Anantapur District, Andhra Pradesh
}

\author{
Ambiga $\mathrm{K}^{1 *}$ \\ ${ }^{1 *}$ Assistant Professor, Department of Civil \& Strucutral Engineering, SCSVMV, Enathur, \\ Kanchipuram - 631 561, Tamilnadu, India.
}

\begin{abstract}
The aim of the project is to assess the suitability of groundwater for human consumption based on the computed water quality index values, characteristics of groundwater and assessment of water quality. The water quality index (WQI) is main tool to determine the drinking water quality in urban, rural and industrial area. This means as an index reflecting the composite influence of different water quality parameters which is considered and taken for calculation of water quality index. In the present study, fifteen groundwater samples were collected from the Budigumma Village Anantpur district in the state Andhra Pradesh in in india Nine water quality parameters have been considered for the calculation of water quality index viz. $\mathrm{pH}$, total hardness (TH), total dissolved solid (TDS), calcium (Ca), magnesium ( $\mathrm{Mg}$ ), nitrates $\left(\mathrm{NO}_{3}\right)$, chlorides $(\mathrm{Cl})$, sulphates $\left(\mathrm{SO}_{4}\right)$, fluorides $(\mathrm{F})$. The World Health Organization (WHO) has been considered to assess the suitability of groundwater for drinking purposes and for the calculation of WQI. The WQI index for the same has been calculated and the values ranged from 97.78 to 108.37 . The current study shows that $87 \%$ area is falling under the poor category for drinking water and the remaining $13 \%$ comes under as good for drinking purposes as per the WQI classification. The analysis reveals the fact that the ground water of this village needs a degree of treatment before consumption and needs to be protected from further contamination.
\end{abstract}

Keywords : Groundwater, Water Qulaity Index, Physical characteristics, Chemical characteristics, Water classification.

\section{Introduction}

Groundwater is an important source of water supply throughout the world. It occurs almost everywhere beneath the earth surface not in a single widespread aquifer but in multiple of local aquifer systems and compartments that have similar characters ${ }^{1}$. Groundwater is a finite resource and it is a rare benefit in many parts of the world. In the countries where the water is a limited resource, the competition is rampant among agriculture, industry and domestic use ${ }^{2}$. 
Ground water quality has become an important water resource issue due to rapid increase in population, rapid industrial development, increasing mining and petroleum operations and too much use of fertilizers and pesticides in agriculture ${ }^{3}$. Most of the population in India use ground water as its primary source of drinking water $^{4}$.

WQI is one of the most effective tools to communicate information on the quality of water to the concerned citizens and policy-makers ${ }^{5}$. WQI is one of the most effective tools to communicate information on the quality of any water body. WQI is a mathematical equation used to transform large number of water quality data into a single number. The water quality of the study was determined for all samples using the weighted arithmetic index method ${ }^{6}$. The present study deals with the ground water quality index of Budigumma Village, Anantapur district in the state Andhra Pradesh in India. In this context, to create environmental awareness among the students and public. Study of water quality index of this village has been undertaken.

\section{Experimental}

Water samples were collected in 15 well station points in Budigumma Village, Anantapur district in the state Andhra Pradesh. The samples were collected as per the standard procedural method for the physico - chemical analysis of various parameters. All reagents were of analytical grade and solutions were made of distilled water. Various water quality parameters such as $\mathrm{pH}$, total hardness $(\mathrm{TH})$, total dissolved solid (TDS), calcium $(\mathrm{Ca})$, magnesium $(\mathrm{Mg})$, nitrates $\left(\mathrm{NO}_{3}\right)$, chlorides $(\mathrm{Cl})$, sulphates $\left(\mathrm{SO}_{4}\right)$, fluorides $(\mathrm{F})$ were determined using standard analytical methods as shown in Table 1. The instruments used were calibrated before use for observing readings ${ }^{7}$. The repeated measurements were to ensure precision and accuracy of results.

\section{Water Quality Index}

For computing water quality index three steps are followed. In the first step, each of the 9 parameters has been assigned a weight (wi) according to its relative importance in the overall quality of water for drinking purposes ${ }^{8}$. The maximum weight of 5 has been assigned to the parameter nitrate due to its major importance in water quality assessment. Weight of 4 has been given to fluoride 5 .

Second step, relative weight (Wi) is computed from the following equation:

$$
W I=\frac{w i}{\sum_{i=\mathbf{1}}^{n} w i}
$$

Where (Wi) is the relative weight, (wi) is the weight of each parameter and ' $n$ ' is the number of parameters calculated relatively weight (wi) values of each parameter are also given in Table 2.

In the third step, a quality rating scale (qi) for each parameter is assigned by dividing its connections in each water sample by its respective standard according to the guidelines laid down in the BIS and the results is multiplied by 100 :

$$
q i=\mathrm{Ci} / \mathrm{Si} \times 100
$$

Where (qi) is the quality rating, $(\mathrm{Ci})$ is the concentration of each parameter in each water sample in $\mathrm{mg} / \mathrm{l}$, except $\mathrm{pH}$, and ( $\mathrm{Si}$ ) is the BIS (Bureau of Indian standards) ${ }^{9}$ water standard for each chemical parameter in $\mathrm{mg} / \mathrm{l}$ according to the guidelines of the WHO standards ${ }^{10}$.

For computing the WQI, the SI is first determined for each chemical parameter, which is then used to determine the WQI as per the following equation as shown in Table 3.

\section{$\mathrm{SIi}=\mathrm{Wi}{ }^{*} \mathrm{qi}$}

SIi is the sub index of the Ith parameter, qi is the rating based on concentration of $i^{\text {th }}$ parameter and $n$ is the number of parameter ${ }^{11}$. The computed WQI values are classified into five types "excellent water", "good water", "poor water", "very poor water", "water unsuitable for drinking" 12,13 as shown in Table 4. 


\section{Results and Discussion}

The physico-chemical tests were conducted employing standard scientific methods, so as to minimize the determinate errors. Following are the some of the observations revealed from the study of the various water quality parameters as shown in Table 1.

Table 1. Analysis of physico - chemical characteristics of groundwater samples

\begin{tabular}{|c|c|c|c|c|c|c|c|c|c|c|c|c|}
\hline $\begin{array}{c}\text { Well } \\
\text { No. }\end{array}$ & $\begin{array}{c}\text { Turbidity } \\
\text { NTU }\end{array}$ & $\begin{array}{c}\text { TDS } \\
\mathbf{m g} / \mathbf{l}\end{array}$ & $\mathbf{p H}$ & $\begin{array}{c}\text { Total } \\
\text { Alkalinity } \\
\mathbf{m g} / \mathbf{l}\end{array}$ & $\begin{array}{c}\mathbf{T H} \\
\mathbf{m g} / \mathbf{l}\end{array}$ & $\begin{array}{c}\mathbf{C a} \\
\mathbf{m g} / \mathbf{l}\end{array}$ & $\begin{array}{c}\mathbf{M g} \\
\mathbf{m g} / \mathbf{l}\end{array}$ & $\begin{array}{c}\mathbf{I r o n} \\
\mathbf{m g} / \mathbf{l}\end{array}$ & $\begin{array}{c}\text { Nitrate } \\
\mathbf{m g} / \mathbf{l}\end{array}$ & $\begin{array}{c}\mathbf{C l} \\
\mathbf{m g} / \mathbf{l}\end{array}$ & $\begin{array}{c}\mathbf{F} \\
\mathbf{m g} / \mathbf{l}\end{array}$ & $\begin{array}{c}\mathbf{S O}_{\mathbf{4}} \\
\mathbf{m g} / \mathbf{l}\end{array}$ \\
\hline 1 & 2 & 1150 & 7.7 & 360 & 400 & 120 & 42 & 0.02 & 28 & 280 & 1.1 & 72 \\
\hline 2 & 2 & 1100 & 7.6 & 440 & 440 & 120 & 46 & 0.02 & 27 & 280 & 1.1 & 82 \\
\hline 3 & 2 & 1100 & 7.9 & 360 & 400 & 120 & 42 & 0.02 & 26 & 240 & 1.1 & 78 \\
\hline 4 & 2 & 1015 & 7.8 & 400 & 440 & 80 & 46 & 0.02 & 28 & 240 & 1.2 & 72 \\
\hline 5 & 2 & 1100 & 7.8 & 400 & 320 & 80 & 34 & 0.02 & 27 & 240 & 1.1 & 76 \\
\hline 6 & 2 & 1100 & 7.8 & 550 & 360 & 80 & 38 & 0.02 & 28 & 320 & 1.2 & 72 \\
\hline 7 & 2 & 1100 & 7.7 & 360 & 400 & 120 & 42 & 0.02 & 27 & 320 & 1.1 & 78 \\
\hline 8 & 2 & 1050 & 7.6 & 320 & 400 & 80 & 42 & 0.02 & 27 & 240 & 1.2 & 78 \\
\hline 9 & 2 & 1200 & 7.9 & 60 & 440 & 120 & 46 & 0.02 & 28 & 280 & 1.2 & 78 \\
\hline 10 & 2 & 1200 & 7.7 & 400 & 440 & 80 & 46 & 0.02 & 27 & 240 & 1.1 & 72 \\
\hline 11 & 2 & 1100 & 7.6 & 360 & 400 & 80 & 42 & 0.02 & 27 & 240 & 1.2 & 78 \\
\hline 12 & 2 & 1200 & 7.9 & 320 & 360 & 80 & 38 & 0.02 & 27 & 240 & 1.2 & 82 \\
\hline 13 & 2 & 1050 & 7.7 & 440 & 400 & 120 & 42 & 0.02 & 28 & 280 & 1.2 & 72 \\
\hline 14 & 2 & 1050 & 7.8 & 400 & 440 & 80 & 46 & 0.02 & 28 & 280 & 1.2 & 72 \\
\hline 15 & 2 & 1100 & 7.8 & 400 & 320 & 80 & 34 & 0.02 & 28 & 240 & 1.1 & 86 \\
\hline
\end{tabular}

Table 2. WHO standards weight (wi) and calculated relative weight (Wi) for each parameter

\begin{tabular}{|l|l|l|l|}
\hline \multicolumn{5}{|l|}{ Relative Weight (Wi) values of each parameter } \\
\hline Parameters & $\begin{array}{l}\text { Indian } \\
\text { Standard }\end{array}$ & $\begin{array}{l}\text { Weitht } \\
\text { (wi) }\end{array}$ & $\begin{array}{l}\text { Relative Weight } \\
\text { (Wi) }\end{array}$ \\
\hline pH & $6.5-8.5$ & 4 & 0.1333 \\
\hline TDS & $500-2000$ & 4 & 0.1333 \\
\hline $\mathrm{Th}$ & $300-600$ & 2 & 0.0667 \\
\hline $\mathrm{Ca}$ & $75-200$ & 2 & 0.0667 \\
\hline $\mathrm{Mg}$ & $30-100$ & 2 & 0.0667 \\
\hline Nitrate & $1-45$ & 5 & 0.1667 \\
\hline Chloride & $250-1000$ & 3 & 0.1 \\
\hline Flouride & $1-1.5$ & 4 & 0.1333 \\
\hline Sulphate & $200-400$ & 4 & 0.1333 \\
\hline Total & & $\mathbf{3 0}$ & $\mathbf{1}$ \\
\hline
\end{tabular}


Table 3. Water classification of each groundwater sample for Quality rating (Qi), Sub index (SIi) and WQI

\begin{tabular}{|c|c|c|c|c|c|c|c|c|c|c|c|c|c|c|c|c|c|c|c|}
\hline \multirow{2}{*}{$\begin{array}{l}\text { Well } \\
\text { No. }\end{array}$} & \multicolumn{2}{|c|}{$\mathbf{P H}$} & \multicolumn{2}{|c|}{ TDS } & \multicolumn{2}{|c|}{ TH } & \multicolumn{2}{|c|}{$\mathrm{Ca}$} & \multicolumn{2}{|c|}{ Mg } & \multicolumn{2}{|c|}{ Nitrate } & \multicolumn{2}{|c|}{ Chloride } & \multicolumn{2}{|c|}{ Fluoride } & \multicolumn{2}{|c|}{ Sulphate } & \multirow[t]{2}{*}{ WQI } \\
\hline & Qi & Sli & Qi & Sli & Qi & Sli & Qi & Sli & Qi & Sli & Qi & Sli & Qi & Sli & Qi & Sli & Qi & Sli & \\
\hline 1 & 90.59 & 12.08 & 230 & 30.7 & 133.3 & 8.9 & 160.0 & 10.7 & 140.00 & 9.34 & 62.22 & 10.37 & 112.00 & 11.20 & 73.33 & 9.78 & 36.00 & 4.80 & 107.78 \\
\hline 2 & 89.41 & 11.92 & 220 & 29.3 & 146.7 & 9.8 & 160.0 & 10.7 & 153.33 & 10.23 & 60.00 & 10.00 & 112.00 & 11.20 & 73.33 & 9.78 & 41.00 & 5.47 & 108.37 \\
\hline 3 & 92.94 & 12.39 & 220 & 29.3 & 133.3 & 8.9 & 160.0 & 10.7 & 140.00 & 9.34 & 57.78 & 9.63 & 96.00 & 9.60 & 73.33 & 9.78 & 39.00 & 5.20 & 104.82 \\
\hline 4 & 91.76 & 12.23 & 203 & 27.1 & 146.7 & 9.8 & 106.7 & 7.1 & 153.33 & 10.23 & 62.22 & 10.37 & 96.00 & 9.60 & 80.00 & 10.66 & 36.00 & 4.80 & 101.85 \\
\hline 5 & 91.76 & 12.23 & 220 & 29.3 & 106.7 & 7.1 & 106.7 & 7.1 & 113.33 & 7.56 & 60.00 & 10.00 & 96.00 & 9.60 & 73.33 & 9.78 & 38.00 & 5.07 & 97.79 \\
\hline 6 & 91.76 & 12.23 & 220 & 29.3 & 120.0 & 8.0 & 106.7 & 7.1 & 126.67 & 8.45 & 62.22 & 10.37 & 128.00 & 12.80 & 80.00 & 10.66 & 36.00 & 4.80 & 103.76 \\
\hline 7 & 90.59 & 12.08 & 220 & 29.3 & 133.3 & 8.9 & 160.0 & 10.7 & 140.00 & 9.34 & 60.00 & 10.00 & 128.00 & 12.80 & 73.33 & 9.78 & 39.00 & 5.20 & 108.08 \\
\hline 8 & 89.41 & 11.92 & 210 & 28.0 & 133.3 & 8.9 & 106.7 & 7.1 & 140.00 & 9.34 & 60.00 & 10.00 & 96.00 & 9.60 & 80.00 & 10.66 & 39.00 & 5.20 & 100.72 \\
\hline 9 & 92.94 & 12.39 & 240 & 32.0 & 146.7 & 9.8 & 160.0 & 10.7 & 153.33 & 10.23 & 62.22 & 10.37 & 112.00 & 11.20 & 80.00 & 10.66 & 39.00 & 5.20 & 112.50 \\
\hline 10 & 90.59 & 12.08 & 240 & 32.0 & 146.7 & 9.8 & 106.7 & 7.1 & 153.33 & 10.23 & 60.00 & 10.00 & 96.00 & 9.60 & 73.33 & 9.78 & 36.00 & 4.80 & 105.37 \\
\hline 11 & 89.41 & 11.92 & 220 & 29.3 & 133.3 & 8.9 & 106.7 & 7.1 & 140.00 & 9.34 & 60.00 & 10.00 & 96.00 & 9.60 & 80.00 & 10.66 & 39.00 & 5.20 & 102.06 \\
\hline 12 & 92.94 & 12.39 & 240 & 32.0 & 120.0 & 8.0 & 106.7 & 7.1 & 126.67 & 8.45 & 60.00 & 10.00 & 96.00 & 9.60 & 80.00 & 10.66 & 41.00 & 5.47 & 103.68 \\
\hline 13 & 90.59 & 12.08 & 210 & 28.0 & 133.3 & 8.9 & 160.0 & 10.7 & 140.00 & 9.34 & 62.22 & 10.37 & 112.00 & 11.20 & 80.00 & 10.66 & 36.00 & 4.80 & 106.01 \\
\hline 14 & 91.76 & 12.23 & 210 & 28.0 & 146.7 & 9.8 & 106.7 & 7.1 & 153.33 & 10.23 & 62.22 & 10.37 & 112.00 & 11.20 & 80.00 & 10.66 & 36.00 & 4.80 & 104.39 \\
\hline 15 & 91.76 & 12.23 & 220 & 29.3 & 106.7 & 7.1 & 106.7 & 7.1 & 113.33 & 7.56 & 62.22 & 10.37 & 96.00 & 9.60 & 73.33 & 9.78 & 43.00 & 5.73 & 98.83 \\
\hline
\end{tabular}


Table 4: Water quality classification based on WQI value

\begin{tabular}{|c|c|c|c|}
\hline WQI Value & Water quality & Well Number & $\begin{array}{c}\text { \% of Water } \\
\text { Samples }\end{array}$ \\
\hline$<50$ & Excellent & Nil & 0 \\
\hline $50-100$ & Good water & 5,15 & 13 \\
\hline $100-200$ & Poor water & $\begin{array}{c}1,2,3,4,6,7,8,9,10, \\
11,12,13,14\end{array}$ & 87 \\
\hline $200-300$ & Very poor water & Nil & 0 \\
\hline$>300$ & $\begin{array}{c}\text { Water unsuitable for } \\
\text { drinking }\end{array}$ & Nil & 0 \\
\hline
\end{tabular}

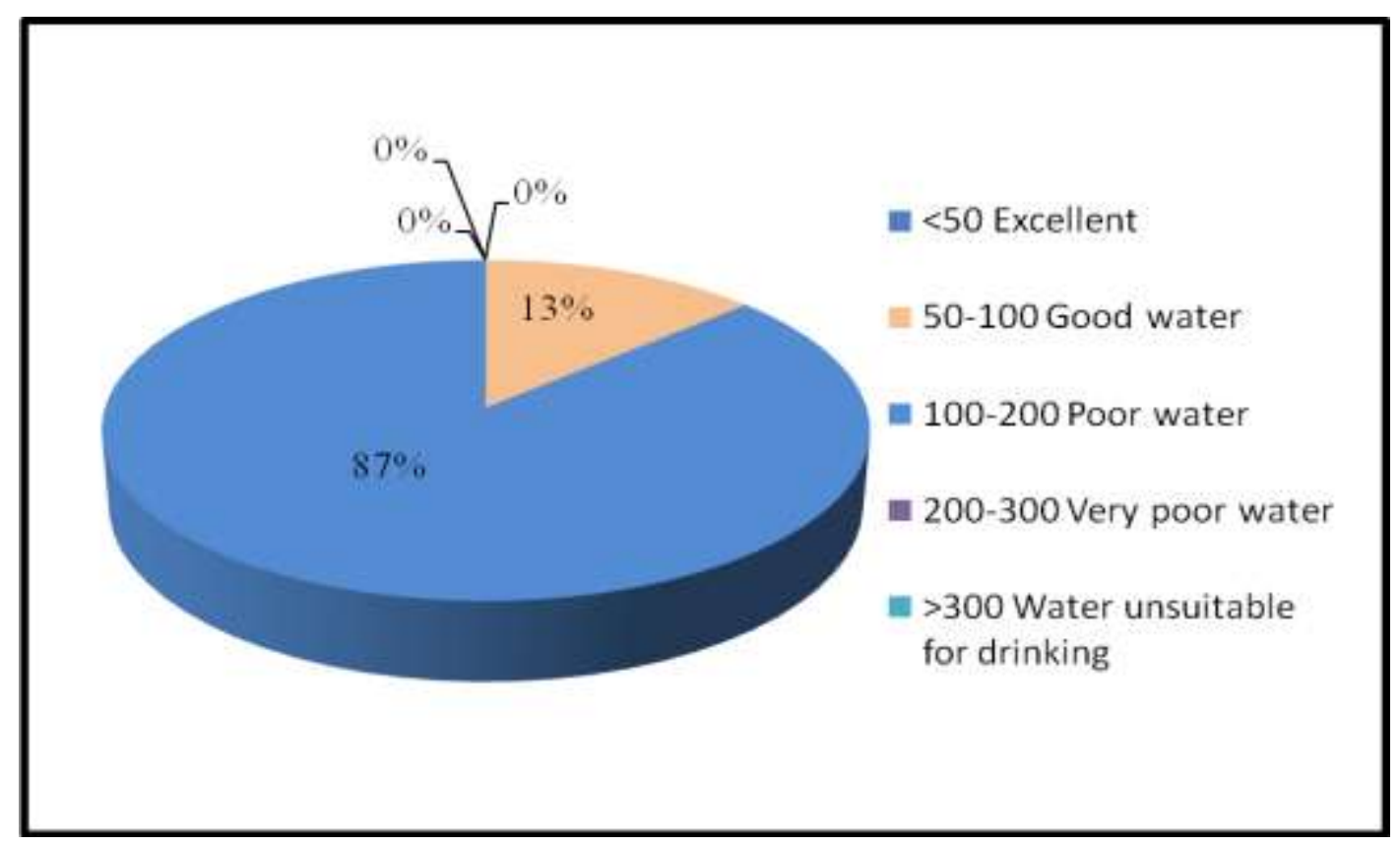

Figure 1. Percentage of well sampling points

The results revealed that, totally nine parameters contain $\mathrm{pH}$, total hardness $(\mathrm{TH})$, total dissolved solid (TDS), calcium $(\mathrm{Ca})$, magnesium $(\mathrm{Mg})$, nitrates $\left(\mathrm{NO}_{3}\right)$, chlorides $(\mathrm{Cl})$, sulphates $\left(\mathrm{SO}_{4}\right)$, fluorides $(\mathrm{F})$ has been used by WQI. The range of WQI calculated from (97.79-108.37) as shown in Table 3. Water quality classification based on WQI value as excellent water quality has less than $50 \mathrm{WQI}$ values for the well number as zero. Good water quality has been WQI values in the range of 50-100 for the well number 5 and 15 as $13 \%$ of water samples as shown in figure 1. Poor water quality has WQI values ranged from 100-200 for the various well number $1,2,3,4,6,7,8,9,10,11,12,13$ and 14 as $87 \%$ of water samples are present as shown in figure 1 . Very poor quality have WQI values ranged from 200-300 for the well number as zero. The water is unfit for usage has WQI values greater than 300 for well as zero.

\section{Conclusions}

The ground water which was taken from the various places in Budigumma Village was analyzed. The analysis of experimental investigation on quality of groundwater using nine physico-chemical parameters of the study area indicate that in general about the water quality was good and poor. In this study, the computed WQI values range from 97.79-108.37. The Percentage of water quality index shows that maximum in the thirteen sample points. The overall view of the Water Quality Index of the present study zone had a higher WQI value indicating the deteriorated water quality. Apart from ground water assessment, the WQI model can be used wide ranging of applications. The analysis reveals that the groundwater of the area needs certain degree of treatment before consumption, and it also needs to be protected from the perils of contamination. 


\section{References}

1. Chandra Sekhar, M., et al., The use of DRASTIC Modeling Indices for the Assessment of Groundwater Pollution Potential, Impacts of Urban Growth on Surface Water and Ground Water Quality (Proceedings of IUGG 99 Symposium HSS, Birmingham, IAHS Pub. No. 259. 1999.

2. Patil Nirdosh et al., Study on the physico-chemical characteristics of groundwater of Gulbarga city Karnataka, International Journal of Applied Biology and Pharmaceutical Technology, 2011, 1 (2), 518523.

3. Bajpayee et al., Assessment by Multivariate Statistical Analysis of Ground Water Geochemical Data of Bankura, India, International Journal of Environmental Sciences, 2012, 3 (2), 870-880.

4. Raja, P., et al., Evaluation of physical and chemical parameters of river Kaveri, Tiruchirappalli, Tamil Nadu, India, Journal of Environmental Biology, 2008, 29 (5), 765-768.

5. Ahmad, I., et al., Determination of Water Quality Index (WQI) for Qalyasan Stream in Sulaimani City, Kurdistan Region of IRAQ, International Journal of Plant, Animal and Environmental Sciences, 2012, 2 (4) 148-157.

6. Chenini, I., et al., Evaluation of Ground Water Quality Using Multiple Linear Regression and Structural Equation Modeling, International Journal of Environmental Science and Technology, 2009, 6 (3), 509519.

7. Bharti, N., et al., Water Quality Indices Used for Surface Water Vulnerability Assessment, International Journal of Environmental Sciences, 2011, 2 (1), 154-173.

8. Dhakad, N.K., et al. Water Quality Index of Ground Water (GWOI) of Jhabua Town, M.P. (India), Journal of Environmental Research and Development, 2008, 2 (3), 443-446.

9. BIS, Indian Standard for Drinking Water Specification - 10500. Bureau of Indian Standards, New Delhi. 1992.

10. WHO Guidelines for Drinking Water, vol. 1, WHO, Geneva, Switzerland, 1984.

11. Charmaine Jerome et al., Evaluation of Water Quality Index and Its Impact on the Quality of Life in an Industrial Area in Bangalore, South India, American Journal of Scientific and Industrial Research, 2010, 1 (3), 595-603.

12. Elangovan, N.S., et al., Assessment of Groundwater Quality along the Cooum River, Chennai, Tamil Nadu, Indian Journal of Chemistry, Article ID 672372. 10, 2013, 2013, 1-10.

13. Usharani, K., et al., Physico-chemical and bacteriological characteristics of Noyyal River and Ground Water Quality of Perur, India, Journal of Applied Sciences \& Environmental Management, 2010, 14 (2), 29-35. 